\title{
Modulation of Yield and Yield Attributes of Transplanted Aman Rice through Organic and Inorganic Fertilization in Terrace Soil
}

\author{
Md. Ashraful Alam, Md. Mizanur Rahman, Md. Arifur Rahman Khan, Md. Humayun Kabir Shiragi, \\ Majharul Islam, and Monjur Morshed
}

\section{ABSTRACT}

Rice production has increased almost doubled over the last decade in Bangladesh as a result of additional application of chemical fertilizers and high yielding varieties. Present experiment was undertaken for elucidating the combined effect of organic materials $(O M)$ and nitrogen $(N)$ fertilizer on yield contributing attributes and yield of transplanted aman ( $T$. aman) rice. Experiment was set in a factorial randomized complete block design (RCBD) with three replications. Five types of OMs viz. RS (rice straw), VC (vermicompost), RHB (rice husk biochar), CD (cowdung) and PM (poultry manure) considering two ton carbon per hectare and three level of $\mathrm{N}$ viz. $\mathrm{N}_{0}, \mathrm{~N}_{100}$ and $\mathrm{N}_{150} \mathrm{~kg} \mathrm{ha}^{-1}$ were used in this experiment. Findings revealed that among the five OMs; cowdung significantly improved the studied parameters. Besides $150 \mathrm{~kg} \mathrm{ha}^{-1}$ dose of $\mathrm{N}$ has pronounced effect on the grain yield of $T$. aman rice. In general OMs alone cannot contribute to the maximum yield and yield contributing parameters. Maximum plant height $(98.5 \mathrm{~cm})$, no of tillers (20), no of effective tillers (18), no of grains $(145.0 \mathrm{~g})$, no of filled grains (138), no of unfilled grains (7.0) per panicle, length of panicle $(27.5 \mathrm{~cm}), 1000$-seed weight $(23.65 \mathrm{~g})$, straw yield $\left(8.97 \mathrm{t} \mathrm{ha}^{-1}\right)$, grain yield $\left(5.41 \mathrm{t} \mathrm{ha}^{-1}\right)$ and biological yield $\left(14.34 \mathrm{tha}^{-1}\right)$ was attributed by the mixed application of $P M$ and $N_{150}$ dose of nitrogen. While maximum harvest index $(\mathbf{4 5 . 0 9 \%})$ was found in the plot received $\mathrm{RS}$ in combination of $\mathrm{N}_{150}$ treatment and its minimum value was recorded also solely in RS treated plot. Findings suggest that the use of $P M$ along with $150 \mathrm{~kg} \mathrm{ha}^{-1} \mathrm{~N}$ can render superior crop growth and yield of $T$. aman rice.

Keywords: Nitrogenous fertilizer, Organic amendment, Terrace soil, T. aman rice and Yield.
Submitted : September 08, 2021

Published : October 12, 2021

ISSN: $2684-1827$

DOI: 10.24018 /ejfood.2021.3.5.372

Md. Ashraful Alam*

Department of Soil Science, Bangabandhu Sheikh Mujibur Rahman Agricultural University, Gazipur 1706, Bangladesh. (e-mail: ashraful@bsmrau.edu.bd) Md. Mizanur Rahman

Department of Soil Science, Bangabandhu Sheikh Mujibur Rahman Agricultural University, Gazipur 1706, Bangladesh.

(e-mail: mizan@bsmrau.edu.bd)

Md. Arifur Rahman Khan

Department of Agronomy, Bangabandhu Sheikh Mujibur Rahman Agricultural University, Gazipur 1706, Bangladesh

(e-mail: arif@bsmrau.edu.bd)

Md. Humayun Kabir Shiragi

Soil Physics and Mineralogy Division,

Soil Resource Development Institute, Dhaka-1215, Bangladesh.

(e-mail: shiragi54@gmail.com)

Majharul Islam

Department of Soil Science, Bangabandhu Sheikh Mujibur Rahman Agricultural University, Gazipur 1706, Bangladesh. \&

Soil Science Division, Bangladesh Institute of Nuclear Agriculture,

Mymensingh-2202, Bangladesh.

(e-mail: m.islambau03@gmail.com)

Monjur Morshed

Department of Soil Science, Bangabandhu Sheikh Mujibur Rahman Agricultural University, Gazipur 1706, Bangladesh. (e-mail: mmorshed3012@gmail.com)

*Corresponding Author

\section{INTRODUCTION}

Rice cultivation has a prime role in the agriculture of Bangladesh covering $77.96 \%$ of total cropped area [1]. About $48 \%$ of rural employment are engaged in rice farming, two-third of calorie supply and one half of the total protein intake of a person in the country comes from rice. Besides rice sector has a pivotal role in one-half of agricultural gross domestic product (GDP) as well as onesixth of the national income in Bangladesh (BRKB, 2021). Unfortunately, the general yield $\left(2.74 \mathrm{t} \mathrm{ha}^{-1}\right)$ level of rice is every low in the country as compared to other rice growing countries like South Korea and japan where the approximate yield is 7.0 to $6.22 \mathrm{t} \mathrm{ha}^{-1}$ respectively [2]. Rice is grown in three seasons viz. Aus (May-August), Aman (AugustDecember) and Boro (December-April) in about 10.5 million hectares of land which has remained unchanged over the last few decades [3]. Rice production could fall by $8 \%$ as early as 2050 because of imbalanced nutrients use solely as inorganic fertilizers. Bangladesh is a densely populated country and its population is growing by two million in every year which may increase by another 30 million in the next 20 years. During this period rice cultivated area may reduce to 10.28 million hectares; therefore, it's a prime 
concern to increase the yield of rice from present $2.74 \mathrm{t} \mathrm{ha}^{-1}$ to $3.74 \mathrm{t} \mathrm{ha}^{-1}$ on an average [4]. Another alarming concern is climate change and its variability for declining crop yields and agricultural stability [5]. Depletion of organic matters in the farm soil has caused significant yield reduction which has already been reported by scientist due to climate change as organic matter is the vital source of nutrients mainly $\mathrm{N}, \mathrm{P}$ and S. Organic matter is essential for soil health and sustainability as it is the lifeblood of soil. Intensive cultivation solely relying on inorganic fertilizers with little or no organic fertilizer resulted in lower carbon content in tropical and subtropical soils [6]. Nitrogen is an essential element for the rice production and plays a significant role in plant growth, yield and quality of rice and the importance of nitrogenous fertilizers in achieving higher yield has been remarkable especially for the sustainability of modern rice varieties. But exogenous use of excess $\mathrm{N}$ fertilizers results lodging of plants, enhance growth duration, increase susceptibility to pests and diseases culminating in the reduction of yields [7]. In this case, smart fertilizer management is very important for increasing rice yields as well as to reduce cost of fertilizers [8]. Growth of plants substantially disrupted when nitrogen supply became minimal which ultimately reduce the yield. Besides, indiscriminate use of $\mathrm{N}$ fertilizers may reduce the yield. It is proved that chemical fertilizer can supply nutrients for plant growth but can't improve soil quality. In this aspects, organic materials is a trusted weapon for supplying nutrients as well as restoring soil health. Continuous application of chemical fertilizers is harmful for environments that's why combined use of organic and inorganic sources of nutrients is crying need for ensuring safe and quality food [9]. The addition of organic materials and $\mathrm{N}$ fertilizer in combination could significantly improve soil health in tropical agriculture's wetland paddy system [10]. Integrated use of organic manures and chemical fertilizers would be promising not only for ensuring greater stability in production but also for maintaining soil fertility [11]. In such case, integrated plant nutrition system can be a good option for producing higher yield instead of sole fertilizer use [12]. The appropriate identification and management of soil fertility problems is a prerequisite to promote crop production and maintain high performance over time. Therefore, the use of organic fertilizers in integration with inorganic fertilizers is very important to improve soil fertility and productivity of crops. The increase in the use of inorganic fertilizers in the production of crops degrades soil health and cause hazards for health and quality food. It is an important issue that has been recently drawn the attention of people towards organic agriculture [13]. Judicial use of nutrients through organic sources such as farm manure, vermicompost, green manure, and bio-fertilizers maintains soil fertility and produces maximum yields at optimal input levels [14]. However, there is not enough information for the right sources of organic fertilizers and the right combinations of organic and inorganic fertilizers for ricebased crop systems to increase yields and improve soil fertility. Efforts are required to formulate input packages with a combination of organic and inorganic fertilizers. Therefore, this study was conducted to evaluate the effects of organic materials and $\mathrm{N}$ fertilizers on the yield and yield contributing attributes of T. aman rice.

\section{MATERIALS AND METHODS}

\section{A. Description of the Study Site}

The study was conducted at the Research field as well as in the Laboratory of Department of Soil Science, Bangabandhu Sheikh Mujibur Rahman Agricultural University (BSMRAU), Gazipur 1706, Bangladesh. The study site is located at $24.09^{\circ} \mathrm{N}$ latitude and $90.25^{\circ} \mathrm{E}$ longitude with an elevation of $8.2 \mathrm{~m}$ from the sea level. The study site belongs to an agro-ecological zone of Madhupur Tract. The soils of experimental site belong to Salna series and remarked as Shallow Red Brown Terrace soil in Bangladesh classification and Inceptisols as USDA classification [15], which is recognized as silty clay loam soil within the $50 \mathrm{~cm}$ from the surface and is acidic in nature. The climate of the territory is sub-tropical, wet and humid. During June-July (269 to $370 \mathrm{~mm}$ ) heavy rainfall and scanty rain during November to February (0 to $55 \mathrm{~mm}$ ) occurs in the study area.

\section{B. Treatments and Setup of the Experiment}

Rice straw, vermicompost, rice husk biochar, cowdung and poultry manure considering $2 \mathrm{t}$ carbon $\mathrm{ha}^{-1}$ along with 0 , 100 and $150 \mathrm{~kg} \mathrm{~N} \mathrm{ha}^{-1}$ were used in this experiment. The treatments were assigned randomly in a factorial randomized complete block design with three replications. The study was conducted in T. aman season and the test crop was Binadhan-7. The unit plot size was $4 \mathrm{~m} \times 3 \mathrm{~m}$ and each plot was separated by $30 \mathrm{~cm}$ wide well-structured polyethylene lined boundary. The RS was collected from previous season, while RHB was prepared through partial burning in oxygen deficient condition at $350{ }^{\circ} \mathrm{C}$ temperature. One-month-old (accumulated during a pit and picked up after one month) PM and CD were procured from local poultry and dairy farms, respectively. Vermicompost was collected from the Soil Science division, Bangladesh Agricultural Research Institute, Gazipur. All the materials were applied before final land preparation and rice seedlings were transplanted after one week. Twenty-five days old seedlings of Binadhan-7 were transplanted at $20 \mathrm{~cm} \times 20 \mathrm{~cm}$ spacing in the unit plots. Soil test-based fertilizer doses of $\mathrm{P}$, $\mathrm{K}$ and $\mathrm{S}$ were used as triple super phosphate (TSP), muriate of potash (MoP) and gypsum, respectively following the fertilizer recommendation guide [16]. The total amount of TSP, MoP and gypsum were applied during final land preparation and urea was applied in three equal splits at 15 days after transplanting (DAT), at maximum vegetative stage and panicle initiation stage. Intercultural operations were done as and when required. Proper irrigation practices were done maintaining sufficient water throughout the season as and when needed although it is a rainfed crop.

\section{Sampling and Data Collection}

At the time of harvesting five hills were randomly selected from each plot for counting plant height, total number of tillers and total number of effective tillers per hill, panicle length and number of grains, filled grains and unfilled grains per panicle. Plants were cut from five square meter area from the center of each plot for measuring grain 
yield, straw yield, biological yield, Harvest Index and weight of 1000-seeds and yields data were reported at ton per hectors.

\section{Statistical Analysis}

Statistix version 10.0 statistical software was used to analyze the data. ANOVA and univariate analyses were performed. LSD (least significant difference) test was done to separate the treatment means. Microsoft Excel (Office 2007) was used to prepare different graphs.

\section{RESUlTS AND DISCUSSION}

\section{A. Plant Height}

Plant height varied significantly at different organic matter applied plots during this experiment. The maximum plant height was recorded in case of PM treated plot $(91.2$ $\mathrm{cm})$ followed by cowdung $(83.3 \mathrm{~cm})$ and $\mathrm{VC}(82.8 \mathrm{~cm})$. Minimum plant height was observed for RHB $(70.5 \mathrm{~cm})$ where the plant height was recorded $72.5 \mathrm{~cm}$ at RS applied plot. Different plant height was observed for various $\mathrm{N}$ doses $\left(\mathrm{N}_{0}, \mathrm{~N}_{100}\right.$, and $\left.\mathrm{N}_{150}\right)$. The highest plant height (83.2 $\mathrm{cm}$ ) was recorded in $\mathrm{N}_{150}$ followed by $\mathrm{N}_{100}$ and lowest plant height $(80.4 \mathrm{~cm})$ was recorded in $\mathrm{N}_{0}$ treated plots (Fig. 1). The number of internode and their length greatly influence the plant height. Additionally, the genetic makeup and also the environmental factors also affect the plant height. The height of rice plants differed significantly when organic manure is applied rather than the recommended dose of inorganic fertilizers [17], which is consistent with this study. The results from the appliance of inorganic fertilizer alone were not significantly different from the height of rice plants resulting from the appliance of organic alone [18]. Chemical fertilizers applied at various doses have an enormous effect on plant height [19]. Application of organic manure combined with chemical fertilizers performed better in boosting plant height than single treatment [20]. As compared to sole application of the recommended fertilizer dose, the combined application of fertilizers and manure enhanced plant height is similar to our findings [3].
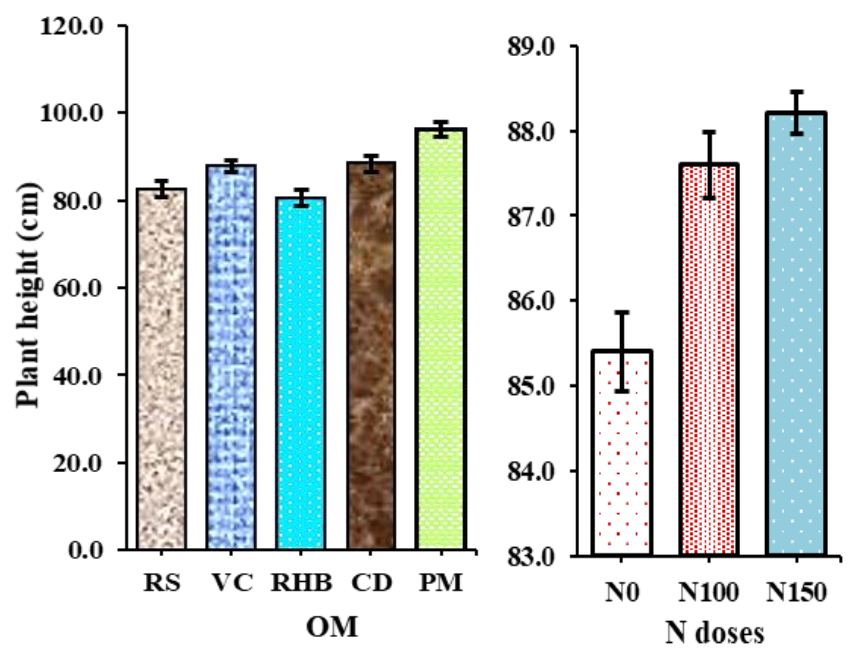

Fig. 1. Effect of different $\mathrm{OM}$ and $\mathrm{N}$ doses on plant height of T.aman rice (Vertical bar indicates the SD of mean).
Plant height could have increased as a results of increased $\mathrm{N}$ availability and therefore the boosting effect of $\mathrm{N}$ on vegetative development by boosting cellular division and elongation [21].

\section{B. Total Number of Tillers per Hill}

The highest number of tillers per hill was recorded in the plots received PM (18) followed by VC (15.1), CD (14.83), and RS (12) respectively and the lowest number of tillers per hill was observed in case of RHB (10.83). In case of $\mathrm{N}$ doses total number of tillers per hill varied with different $\mathrm{N}$ rates. At different doses of $\mathrm{N}$, highest number of tillers per hill was recorded at $\mathrm{N}_{150}$ followed by $\mathrm{N}_{100}$ and $\mathrm{N}_{0}$ which were 15.8, 13.9 and 10, respectively (Fig. 2). Tillering is an important trait for increasing number of panicles and is thereby a very important aspect in increasing rice yield. Study reported the increase in number of tillers in rice plants because of influence of combined application of fertilizers [22]. Consisting with several findings a greater number of tillers per square area can be more because of the more availability of nitrogen which plays a significant role in biological process. Organic matters ensure balanced nutrition for plants specially micronutrients which positively affect the tillers number in rice [23]. Availability of sufficient $\mathrm{N}$ helps many cellular activities at the time of panicle formation which ultimately increase the tiller number [24].
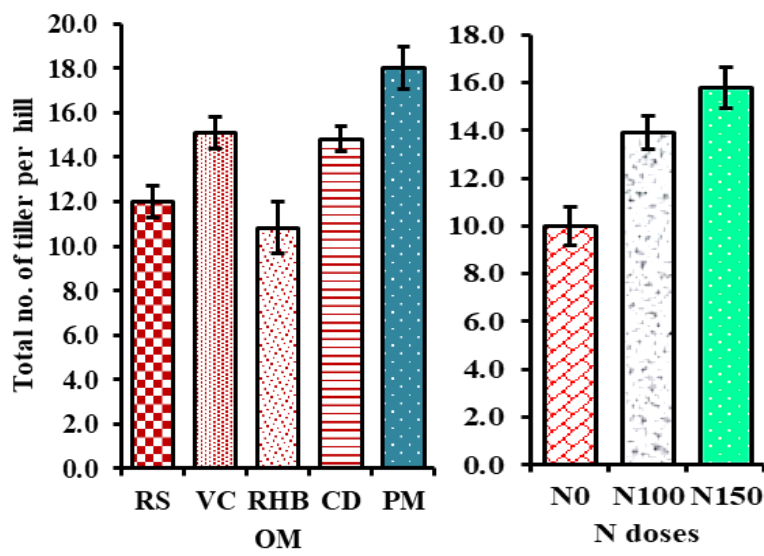

Fig. 2. Effect of different $\mathrm{OM}$ and $\mathrm{N}$ doses on total number of tiller per hill of T.aman rice (Vertical bar indicates the SD of mean).

\section{Number of Effective Tillers per Hill}

Number of effective tillers per hill was found maximum in the poultry manure (16.83) application followed by vermicompost (13.5), cowdung (13.33) and rice straw (11.33) and its lowest number was found in the RHB (11.6) treated plots. In terms of $\mathrm{N}$ application effective tillers was recorded in increasing with the increment of $\mathrm{N}$ doses. $\mathrm{N}_{150}$ treatment provided the best count of effective tiller (14.0) while $\mathrm{N}_{0}$ (12) dose rendered minimal effective tillers per hill non-significantly (Fig. 3). Poultry manure is quite superior to cowdung in case of producing effective tillers [17]. Integrated nutrient management had a considerable effect on number of total and effective tillers per hill [25]. Applying manure or chemical fertilizer to the soil alone improves the number of tillers but applying manure and chemical fertilizer together results in a higher number of tillers [26]. 

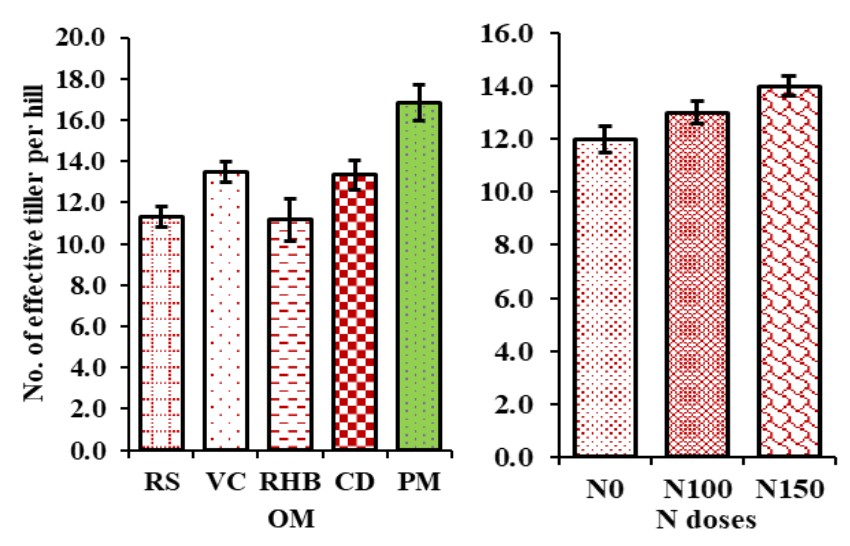

Fig. 3. Effect of different $\mathrm{OM}$ and $\mathrm{N}$ doses on number of effective tiller per hill T. aman rice (Vertical bar indicates the SD of mean).

Rice productivity is largely determined by the number of tillers (the number of tillers with panicles) rather than the total number of tillers. The researcher observed the maximum number of fertile tillers and the number of spikelet per panicle in all treated plants, and it was observed that if we can supplement inorganic fertilizers from organic fertilizers, there is no need to over apply inorganic fertilizers to produce effective tillers, which also helps provide essential micronutrients for plants [23][27].

\section{Panicle Length}

Panicle length $(\mathrm{cm})$ differed in treated plots for the application of different organic matter. The highest panicle length was recorded in case of poultry manure $(26 \mathrm{~cm})$ followed by cowdung $(24.66 \mathrm{~cm})$, vermicompost $(23.16 \mathrm{~cm})$ and rice husk biochar $(23.83 \mathrm{~cm})$ treated plots. On the other hand, lowest panicle length was found in the rice straw $(19.50 \mathrm{~cm})$ applied plot. At different $\mathrm{N}$ doses the panicle length significantly varied from each other. Highest panicle length was recorded at $\mathrm{N}_{150}$ dose $(23.90 \mathrm{~cm})$ followed by $\mathrm{N}_{100}$ dose $(22.90 \mathrm{~cm})$ and its lowest value was conferred by $\mathrm{N}_{0}$ dose $(22.30 \mathrm{~cm})$ is presented in Fig. 4. Increase nitrogen doses affect the growth of panicle length because of involvement of nitrogen in panicle formation and elongation [28]. The length of panicle is an important yield trait of rice as number of spikelet depends on panicle length; positively influencing the yield of rice. According to Kumar and Singh [29] integrating OM with inorganic nutrients source improved the panicle length of rice.

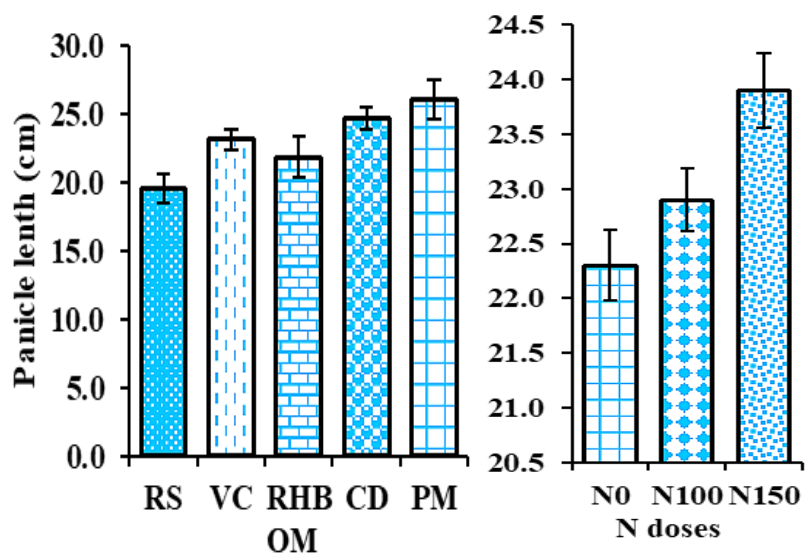

Fig. 4. Effect of different $\mathrm{OM}$ and $\mathrm{N}$ doses on panicle length of T.aman rice (Vertical bar indicates the SD of mean)

\section{E. Number of Grains per Panicle}

Number of grains per panicle was found maximum in poultry manure (139.33) followed by cowdung (134.67), vermicompost (134.33) and rice husk biochar (128.17) respectively and its minimum value was recorded in rice straw (126.50) treated plot (Fig. 5). While $\mathrm{N}_{150}$ (134.40) dose of $\mathrm{N}$ rendered highest grains followed by $\mathrm{N}_{100}$ (133.0) and $\mathrm{N}_{0}(130.40)$. Variation among the number of grains per panicle for different OM's might be due to genetic makeup as well as variation in the photosynthetic activities of plants specially after heading stage. Yield of rice is contributed by the amount of grains in each panicle. Application of organic and nitrogenous fertilizer greatly influence the number of grains in rice as combined use of fertilizer ensure smooth supply plant essential nutrients like N, P and S mainly. An adequate supply of $\mathrm{N}$ contributes to grain formation which increases the number of grains per panicle with the increase of $\mathrm{N}$ level [30].

\section{F. Number of Filled Grains per Panicle}

The highest number of filled grains was recorded in the plots received poultry manure (133.8) followed by cowdung (129.9), vermicompost (127.2) and rice straw (121.0) respectively; whereas the lowest amount was found in the rice husk biochar (120.5) applied plots. In case of $\mathrm{N}$ doses maximum number of filled grains was found at $\mathrm{N}_{150}$ (128.14) followed by $\mathrm{N}_{100}$ (126.8) and $\mathrm{N}_{0}$ (123.9) respectively (Fig. 6). Grains per panicle increase in rice through the utilization of PM [31]. Sohela et al. noticed the substantial impacts on the number of grains in each panicle due to addition of organic and inorganic source of nutrients [20]. Balanced nutrition supplied by integrated means renders maximum vegetative growth of plants which helps to functions the photosynthetic system properly resulting the best grain filling in rice. The enormous and dynamic supply of nutrition organically enhance better tillers formation and grains filling in rice [32].
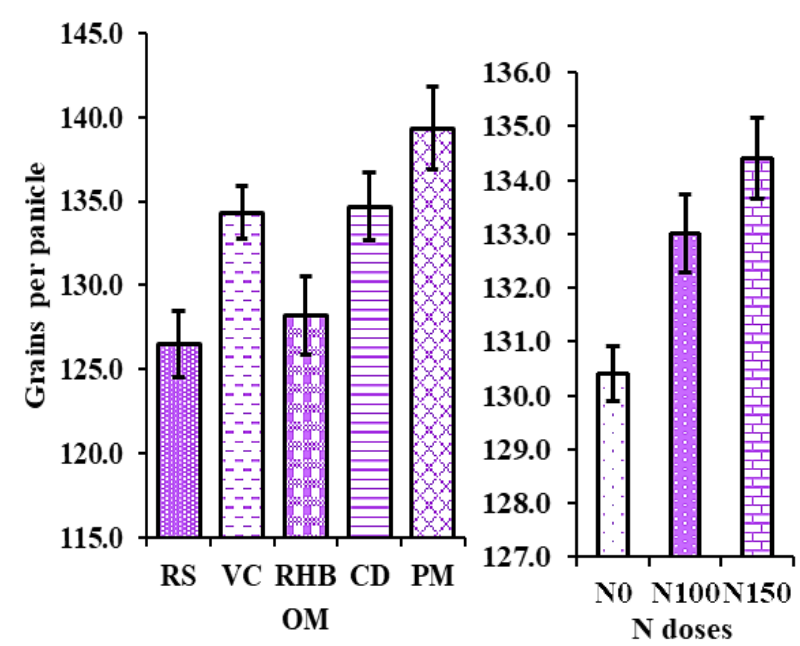

Fig. 5. Effect of different $\mathrm{OM}$ and $\mathrm{N}$ doses on number of grains per panicle of T.aman rice (Vertical bar indicates the SD of mean).

\section{G. Number of Unfilled Grains per Panicle}

The highest number of unfilled grains per panicle was recorded in case of rice husk biochar (7.66) followed by poultry manure (5.60), rice straw (5.50) and vermicompost 
(5.16) treated plots. The lowest number of unfilled grains per panicle was observed for cowdung (4.83) application.
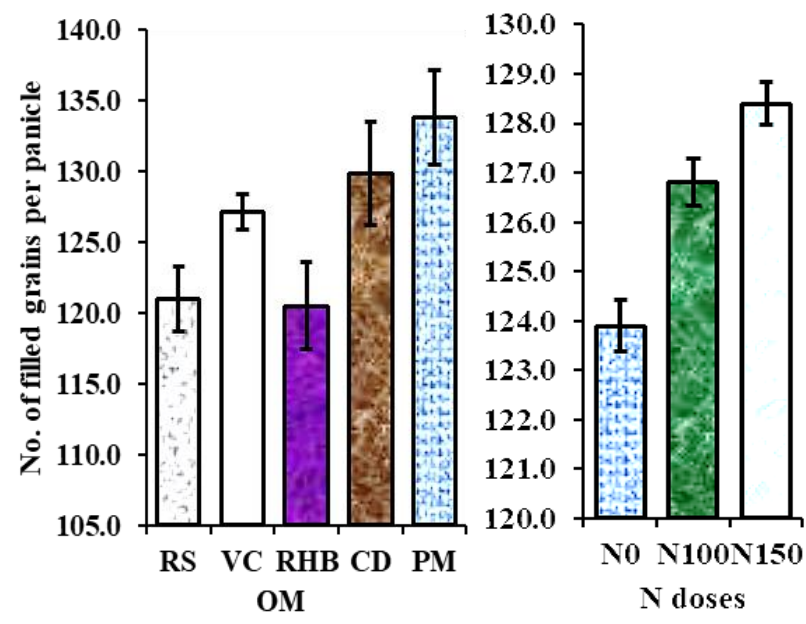

Fig. 6. Effect of different $\mathrm{OM}$ and $\mathrm{N}$ doses on number of filled grains per panicle of T.aman rice (Vertical bar indicates the SD of mean)

On the contrary, in case of $\mathrm{N}$ doses the highest number of unfilled grains per panicle was recorded at $\mathrm{N}_{0}$ (6.5) followed by $\mathrm{N}_{100}(6.2)$ and $\mathrm{N}_{150}(6.0)$ dose treated plots respectively (Fig. 7). The lowest number of unfilled grains per panicle is well expected in any cereal's crops. The traditional explanation for inadequate grain filling is that it is a result of carbon restriction. Recent research has demonstrated that carbohydrate supply should not be a serious issue because they have enough sucrose at the grain-filling stage. The lack of grain filling could be due to low activity of key enzymes involved in carbon metabolism. Proper field measures, such as moderate soil drying throughout the mid and late stages of grain filling, may be able to alleviate some of the problems associated with inadequate grain filling [33].

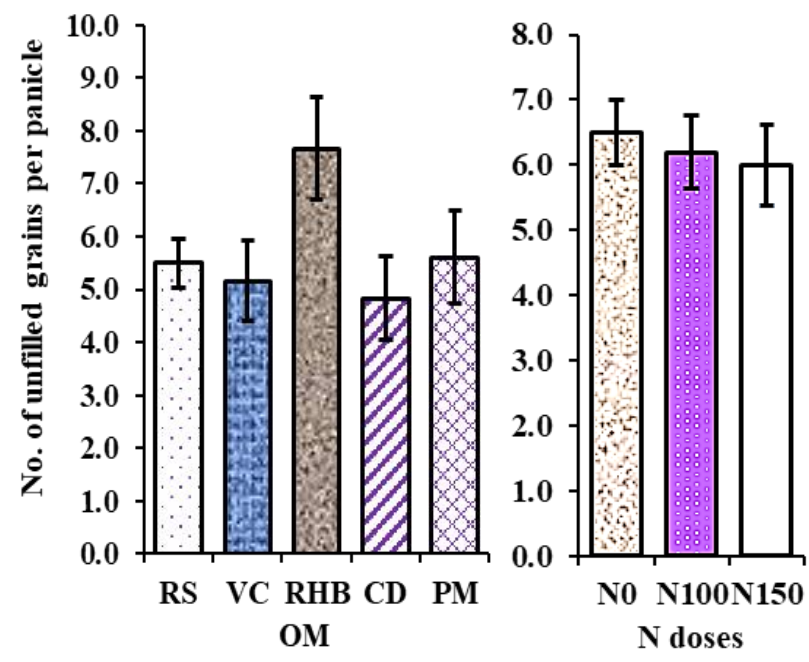

Fig. 7. Effect of different $\mathrm{OM}$ and $\mathrm{N}$ doses on number of unfilled grains per panicle of T.aman rice (Vertical bar indicates the SD of mean).

\section{H. 1000-seed Weight}

Solicitation of diverse $\mathrm{OM}$ and $\mathrm{N}$ nourishment greatly influence 1000 seed weight (TSW) of Binadhan-7 under this study (Table I). Significant variation in TSW was found in case of different organic materials application. Maximum
TSW was recorded in Poultry manure treated plot which was $23.60 \mathrm{~g}$ followed by cowdung, vermicompost and rice husk biochar treated plot, which was $22.98 \mathrm{~g}, 22.50 \mathrm{~g}$ and $22.08 \mathrm{~g}$ respectively. The lowest TSW was found in case of rice straw treated plot which was $20.73 \mathrm{~g}$. While application of different $\mathrm{N}$ doses also positively influences the TSW of Binadhan-7. The highest TSW was found in the plot received $150 \mathrm{~kg} \mathrm{ha}^{-1} \mathrm{~N}$ which was $22.83 \mathrm{~g}$ followed by 100 $\mathrm{kg} \mathrm{ha}^{-1} \mathrm{~N}$ which was $22.05 \mathrm{~g}$ and the minimum TSW was recorded in the plot received no $\mathrm{N}$ fertilizer which was 22.05 g. A significant effect of organic and inorganic fertilizer on 1000-grain weight was concluded by scientist [20]. A substantial change in TSW of rice as exaggerated by variations in fertilizer packages [22]. The improvement in grain yield components might be owing to more availability of water which enhanced the availability and uptake of nutrients resulting in pronounced production and translocations of dry matters from source to sink [34].

TABLE I: EFFECT OF OM AND N DOSES ON 1000 SEED WEIGHT (TSW), GRAIN YIELD (GY), STRAW YIELD (SY), BIOLOGICAL YIELD (BY) AND

\begin{tabular}{|c|c|c|c|c|c|}
\hline $\begin{array}{l}\text { Treatment } \\
\text { factors }\end{array}$ & $\begin{array}{c}\text { TSW } \\
(\mathrm{g})\end{array}$ & $\begin{array}{c}\mathrm{GY} \\
\left(\mathrm{t} \mathrm{ha}^{-1}\right)\end{array}$ & $\begin{array}{c}\text { SY } \\
\left(\mathrm{t} \mathrm{ha}^{-1}\right)\end{array}$ & $\begin{array}{c}\text { BY } \\
\left(\mathrm{t} \mathrm{ha}^{-1}\right)\end{array}$ & $\begin{array}{l}\mathrm{HI} \\
(\%)\end{array}$ \\
\hline \multicolumn{6}{|c|}{ Organic Materials } \\
\hline RS & $20.73^{\mathrm{d}}$ & $4.64^{\mathrm{bc}}$ & $6.18^{\mathrm{b}}$ & $10.82^{\mathrm{c}}$ & $43.03^{\mathrm{a}}$ \\
\hline VC & $22.50^{\mathrm{bc}}$ & $4.85^{b}$ & $7.05^{b}$ & $11.90^{\mathrm{b}}$ & $40.97^{\mathrm{ab}}$ \\
\hline RHB & $22.08^{\mathrm{c}}$ & $4.45^{\mathrm{c}}$ & $6.74^{\mathrm{b}}$ & $11.19^{\mathrm{bc}}$ & $39.89^{\mathrm{ab}}$ \\
\hline $\mathrm{CD}$ & $22.98^{\mathrm{ab}}$ & $4.86^{\mathrm{b}}$ & $6.61^{\mathrm{b}}$ & $11.47^{\mathrm{bc}}$ & $42.41^{\mathrm{ab}}$ \\
\hline PM & $23.60^{\mathrm{a}}$ & $5.33^{\mathrm{a}}$ & $8.19^{\mathrm{a}}$ & $13.53^{\mathrm{a}}$ & $39.57^{\mathrm{b}}$ \\
\hline S.E. $( \pm)$ & 0.37 & 0.14 & 0.42 & 0.46 & 1.56 \\
\hline \multicolumn{6}{|c|}{ Nitrogen doses $\left(\mathrm{kg} \mathrm{ha}^{-1}\right)$} \\
\hline $\mathrm{N}_{0}$ & $22.05^{\mathrm{b}}$ & $4.66^{\mathrm{b}}$ & $6.55^{\mathrm{a}}$ & $11.21^{\mathrm{b}}$ & $41.79^{\mathrm{a}}$ \\
\hline $\mathrm{N}_{100}$ & $22.25^{\mathrm{ab}}$ & $4.84^{\mathrm{ab}}$ & $7.15^{\mathrm{a}}$ & $12.00^{\mathrm{a}}$ & $41.33^{\mathrm{a}}$ \\
\hline $\mathrm{N}_{150}$ & $22.84^{\mathrm{a}}$ & $4.97^{\mathrm{a}}$ & $7.16^{\mathrm{a}}$ & $12.13^{\mathrm{a}}$ & $40.40^{\mathrm{a}}$ \\
\hline S.E. $( \pm)$ & 0.62 & 0.11 & 0.32 & 0.35 & 1.20 \\
\hline
\end{tabular}

Note: $\mathrm{RS}=$ Rice straw; $\mathrm{VC}=$ Vermicompost; $\mathrm{RHB}=$ Rice husk biochar; $\mathrm{CD}=$ Cowdung and $\mathrm{PM}=$ Poultry Manure.

\section{Straw Yield}

Different organic materials and $\mathrm{N}$ doses significantly impacted the straw yield (SY) of Binadhan-7 (Table I). In case of different organic materials treatment maximum straw yield was found in PM treated plot which was $8.19 \mathrm{t}$ $\mathrm{ha}^{-1}$ followed by vermicompost $\left(7.05 \mathrm{t} \mathrm{ha}^{-1}\right)$, rice husk biochar $\left(6.74 \mathrm{t} \mathrm{ha}^{-1}\right)$ and cowdung $\left(6.61 \mathrm{t} \mathrm{ha}^{-1}\right)$ treated plots respectively. The minimum straw yield was found in the rice straw treated plot which was $6.18 \mathrm{t} \mathrm{ha}^{-1}$. Application of different doses of $\mathrm{N}$ fertilizer also influence the straw yield of rice. Highest straw yield was recorded in the plot received $150 \mathrm{~kg} \mathrm{ha}^{-1} \mathrm{~N}$ which was $7.16 \mathrm{t} \mathrm{ha}^{-1}$ followed by $100 \mathrm{~kg} \mathrm{ha}^{-1}$ $\mathrm{N}$ which was $7.15 \mathrm{t} \mathrm{ha}^{-1}$ and the lowest straw yield was found in the plot received no $\mathrm{N}$ fertilizer which was $6.55 \mathrm{t}$ $\mathrm{ha}^{-1}$. The integrated application of organic and inorganic fertilizer resulted in high straw biomass in rice [35]. Alim also found that the straw yield of rice plants varied greatly depending on the type and amount of nitrogen fertilizer used [36]. Total dry matter accumulation of plants varied dramatically under different levels of inorganic fertilizer [18]. Application of different doses of manures and fertilizers influenced the crop characters in terms of plant height and number of total tillers hill ${ }^{-1}$ which resulted in differences of straw yield [37]. 


\section{J. Grain Yield}

Different organic materials and $\mathrm{N}$ doses significantly impacted the grain yield (GY) of Binadhan-7 (Table I). In case of different organic treatment maximum grain yield was found in PM treated plot which was $5.33 \mathrm{t} \mathrm{ha}^{-1}$ followed by Cowdung (4.86 $\left.\mathrm{t} \mathrm{ha}^{-1}\right)$, vermicompost $\left(4.85 \mathrm{t} \mathrm{ha}^{-1}\right)$ and rice straw (4.64 $\left.\mathrm{t} \mathrm{ha}^{-1}\right)$ treated plots respectively. The minimum grain yield was found in the rice husk biochar treated plot which was $4.45 \mathrm{t} \mathrm{ha}^{-1}$. Application of different doses of $\mathrm{N}$ fertilizer also influence the grain yield of rice. The highest grain yield was recorded in the plot received $150 \mathrm{~kg} \mathrm{ha}^{-1} \mathrm{~N}$ which was $4.97 \mathrm{t} \mathrm{ha}^{-1}$ followed by $100 \mathrm{~kg} \mathrm{ha}^{-1}$ $\mathrm{N}$ which was $4.84 \mathrm{t} \mathrm{ha}^{-1}$ and the lowest grain yield was found in the plot received no $\mathrm{N}$ fertilizer which was $4.66 \mathrm{t}$ $\mathrm{ha}^{-1}$. The use of various $\mathrm{OM}$ and inorganic $\mathrm{N}$ fertilizer increased rice grain yields significantly but had no effect on straw yields [38]. Organic fertilizers have a significant influence on growth and productivity of rice. Organic fertilizers can be a better supplement of inorganic fertilizer for better growth and yield. From the economic point of view farmers can use the combination of organic fertilizer and reduced rate of inorganic fertilizers to boost the yield of rice as well as to maintain and improve soil health [39]. Long term addition of manures increased rice and wheat yield positively and the cow dung and rice straw performed better as compared to compost and green manure [40], which is consistent with this study.

\section{K. Biological Yield}

The use of various OM's and $\mathrm{N}$ doses had significantly considerable influence on the biological yield (BY) of Binadhan-7 (Table I). In case of different OM's treatment maximum biological yield was found in PM treated plot which was $13.53 \mathrm{t} \mathrm{ha}^{-1}$ after that VC $\left(11.90 \mathrm{t} \mathrm{ha}^{-1}\right), \mathrm{CD}$ $\left(11.47 \mathrm{t} \mathrm{ha}^{-1}\right)$ and RHB $\left(11.19 \mathrm{t} \mathrm{ha}^{-1}\right)$ treated plots respectively. The minimum biological yield was found in the RS treated plot which was $10.82 \mathrm{t} \mathrm{ha}^{-1}$. Application of various doses of $\mathrm{N}$ fertilizer also influence the biological yield of rice. In the plot that got $150 \mathrm{~kg} \mathrm{ha}^{-1} \mathrm{~N}$ the highest biological yield was recorded which was $12.13 \mathrm{t} \mathrm{ha}^{-1}$ followed by $100 \mathrm{~kg} \mathrm{ha}^{-1} \mathrm{~N}$ which was $12.00 \mathrm{t} \mathrm{ha}^{-1}$ and the plot that received no $\mathrm{N}$ fertilizer had the lowest biological yield of $11.21 \mathrm{t} \mathrm{ha}^{-1}$. In a study, the biological yield was much higher when 50 percent nitrogen from inorganic sources was applied, compared to 25 percent nitrogen from farm yard manure and 25 percent nitrogen from poultry manure [41]. Organic and inorganic N fertilizer treatment had a considerable impact on biological yield [42], which is in line with our findings.

\section{Harvest Index}

The use of various organic materials and $\mathrm{N}$ doses had considerable influence on the Harvest Index (HI) of Binadhan-7 (Table I). In case of different organic materials treatment maximum HI was found in RS treated plot which was $43.03 \%$ followed by CD (42.41\%) and VC (40.97\%) and RHB (39.89\%) treated plots respectively. The minimum HI was found in the PM treated plot which was $39.57 \%$. The use of different doses of $\mathrm{N}$ fertilizer insignificantly influence the HI of rice. The highest HI was recorded in the plot received no $\mathrm{N}$ fertilizer which was $41.79 \%$ after that $100 \mathrm{~kg}$ ha $^{-1} \mathrm{~N}$ which was $41.33 \%$ and the lowest HI was found in the plot received $150 \mathrm{~kg} \mathrm{ha}^{-1} \mathrm{~N}$ fertilizer which was $40.40 \%$. Pramanik et al. reported that when integrated nutrient management was used instead of solely using inorganic fertilizers, the harvest index was distinct [17]. The improved index of harvests represents an increase in physiological capability to mobilize and transform photosynthesis into economically productive organisms. As economic returns are only a fraction of dry matter, the harvest index provides a useful measure of the return potential [43].

\section{Interaction Effect of OM and $N$ fertilizer on Yield and Yield Contributing Characters}

Organic matters are the storehouse of nutrients while applied in addition with $\mathrm{N}$ fertilizer positively impact the growth, yield, and performance of crops. Combined application of $\mathrm{OM}$ and $\mathrm{N}$ fertilizer have significant effects on $\mathrm{T}$. aman rice in terms of plant height, tillers hill ${ }^{-1}$, effective tillers hill ${ }^{-1}$, panicle length, grains panicle ${ }^{-1}$, filled grains panicle ${ }^{-1}$, unfilled grains panicle ${ }^{-1}$, TSW, grains yield, straw yield, biological yield, and HI (Table II and III).

TABLE II: INTERACTION EFFECT OF OM AND N DOSES ON YIELD PARAMETERS OF T. AMAN RICE

\begin{tabular}{|c|c|c|c|c|c|c|c|}
\hline $\mathrm{OM} * \mathrm{~N}$ & $\begin{array}{l}\text { Plant height } \\
(\mathrm{cm})\end{array}$ & $\begin{array}{l}\text { Tillers hill }{ }^{-1} \\
\text { (No.) }\end{array}$ & $\begin{array}{l}\text { Effective } \\
\text { tillers hill }^{-1} \\
\text { (No.) } \\
\end{array}$ & $\begin{array}{c}\text { Panicle } \\
\text { length } \\
(\mathrm{cm})\end{array}$ & $\begin{array}{c}\text { Grain's panicle }{ }^{-1} \\
\text { (No.) }\end{array}$ & $\begin{array}{c}\text { Filled Grains } \\
\text { panicle }^{-1} \\
(\text { No. })\end{array}$ & $\begin{array}{c}\text { Unfilled } \\
\text { Grains panicle } \\
{ }^{1} \text { (No.) } \\
\end{array}$ \\
\hline $\mathrm{RSN}_{0}$ & $83.5^{\text {def }}$ & $11.0^{\mathrm{gh}}$ & $10.0^{\mathrm{g}}$ & $19.5^{\text {gh }}$ & $122.0^{\mathrm{h}}$ & $112.0^{\mathrm{g}}$ & $10.0^{\mathrm{a}}$ \\
\hline $\mathrm{RSN}_{100}$ & $81.5^{\mathrm{f}}$ & $12.0^{\mathrm{fgh}}$ & $10.5^{\mathrm{efg}}$ & $18.5^{\mathrm{h}}$ & $127.5^{\mathrm{efgh}}$ & $119.5^{\mathrm{efg}}$ & $8.0^{\mathrm{ab}}$ \\
\hline $\mathrm{RSN}_{150}$ & $82.5^{\text {ef }}$ & $13.0^{\mathrm{efg}}$ & $11.0^{\mathrm{fg}}$ & $20.5^{\mathrm{fg}}$ & $129.0^{\text {defgh }}$ & $119.5^{\mathrm{efg}}$ & $9.5^{\mathrm{ab}}$ \\
\hline $\mathrm{VCN}_{0}$ & $84.5^{\mathrm{de}}$ & $14.5^{\mathrm{cde}}$ & $13.5^{\mathrm{cde}}$ & $22.5^{\mathrm{de}}$ & $132.0^{\text {cdefgh }}$ & $125.0^{\text {cde }}$ & $7.0^{\mathrm{ab}}$ \\
\hline $\mathrm{VCN}_{100}$ & $90.0^{c}$ & $14.5^{\text {cde }}$ & $13.0^{\text {cdef }}$ & $23.5^{\mathrm{cd}}$ & $135.5^{\text {bcde }}$ & $128.0^{\mathrm{bcd}}$ & $7.5^{\mathrm{ab}}$ \\
\hline $\mathrm{VCN}_{150}$ & $89.0^{\mathrm{c}}$ & $16.5^{\mathrm{bc}}$ & $14.0^{\text {cdef }}$ & $23.5^{\mathrm{cd}}$ & $137.5^{\mathrm{abcd}}$ & $129.5^{\mathrm{bc}}$ & $8.0^{\mathrm{ab}}$ \\
\hline $\mathrm{RHBN}_{100}$ & $81.0^{\mathrm{fg}}$ & $10.5^{\text {hi }}$ & $9.5^{\mathrm{gh}}$ & $21.5^{\mathrm{ef}}$ & $121.0^{\mathrm{h}}$ & $113.5^{\mathrm{fg}}$ & $7.5^{\mathrm{ab}}$ \\
\hline $\mathrm{RHBN}_{150}$ & $82.0^{\text {ef }}$ & $13.5^{\mathrm{def}}$ & $11.5^{\mathrm{efg}}$ & $23.5^{\mathrm{cd}}$ & $126.0^{\mathrm{fgh}}$ & $119.5^{\text {efg }}$ & $6.5^{\mathrm{ab}}$ \\
\hline $\mathrm{CDN}_{0}$ & $86.0^{\mathrm{d}}$ & $13.5^{\mathrm{def}}$ & $12.5^{\mathrm{def}}$ & $24.5^{\mathrm{bc}}$ & $129.0^{\text {defgh }}$ & $120.5^{\mathrm{def}}$ & $8.5^{\mathrm{ab}}$ \\
\hline $\mathrm{CDN}_{100}$ & $90.0^{\mathrm{c}}$ & $15.5^{\mathrm{bcd}}$ & $14.5^{\mathrm{bcd}}$ & $25.0^{\mathrm{bc}}$ & $133.5^{\mathrm{cdef}}$ & $125.5^{\text {cde }}$ & $8.0^{\mathrm{ab}}$ \\
\hline $\mathrm{CDN}_{150}$ & $89.0^{c}$ & $15.5^{\mathrm{bcd}}$ & $14.5^{\text {bcd }}$ & $24.5^{\mathrm{bc}}$ & $138.5^{\mathrm{abc}}$ & $132.5^{\mathrm{abc}}$ & $6.0^{\mathrm{ab}}$ \\
\hline $\mathrm{PMN}_{0}$ & $94.5^{b}$ & $17.0^{\mathrm{b}}$ & $15.0^{\mathrm{bc}}$ & $24.5^{\mathrm{bc}}$ & $133.5^{\mathrm{cdef}}$ & $128.5^{\text {bcd }}$ & $5.0^{\mathrm{b}}$ \\
\hline $\mathrm{PMN}_{100}$ & $95.5^{b}$ & $17.0^{\mathrm{b}}$ & $16.5^{\mathrm{ab}}$ & $26.0^{\mathrm{ab}}$ & $143.5^{\mathrm{ab}}$ & $136.0^{\mathrm{ab}}$ & $7.5^{\mathrm{ab}}$ \\
\hline $\mathrm{PMN}_{150}$ & $98.5^{\mathrm{a}}$ & $20.0^{\mathrm{a}}$ & $18.0^{\mathrm{a}}$ & $27.5^{\mathrm{a}}$ & $145.0^{\mathrm{a}}$ & $138.0^{\mathrm{a}}$ & $7.0^{\mathrm{ab}}$ \\
\hline $\mathrm{SE}( \pm)$ & 1.34 & 1.03 & 1.12 & 0.77 & 4.04 & 3.73 & 2.21 \\
\hline
\end{tabular}


TABLE III: INTERACTION EFFECT OF OM AND N ON 1000 SEED WEIGHT (TSW), GRAIN YIELD (GY), STRAW YIELD (SY), BIOLOGICAL YIELD (BY) AND HARVEST INDEX (HI) OF T. AMAN RICE

\begin{tabular}{|c|c|c|c|c|c|}
\hline $\mathrm{OM} * \mathrm{~N}$ & $\begin{array}{c}\text { TSW } \\
(\mathrm{g})\end{array}$ & $\begin{array}{c}\text { GY } \\
\left(\mathrm{t} \mathrm{ha}^{-1}\right)\end{array}$ & $\begin{array}{c}\text { SY } \\
\left(\mathrm{t} \mathrm{ha}^{-1}\right)\end{array}$ & $\begin{array}{c}\text { BY } \\
\left(\mathrm{t} \mathrm{ha}^{-1}\right)\end{array}$ & $\begin{array}{c}\mathrm{HI} \\
(\%)\end{array}$ \\
\hline $\mathrm{RSN}_{0}$ & $19.65^{\mathrm{f}}$ & $4.60^{\mathrm{d}}$ & $5.94^{\mathrm{de}}$ & $10.54^{\mathrm{e}}$ & $43.67^{\mathrm{ab}}$ \\
\hline $\mathrm{RSN}_{100}$ & $20.7^{\mathrm{ef}}$ & $4.70^{\mathrm{bcd}}$ & $6.94^{\text {bcde }}$ & $11.64^{\text {cde }}$ & $40.33^{\mathrm{abc}}$ \\
\hline $\mathrm{RSN}_{150}$ & $21.88^{\text {cde }}$ & $4.64^{\mathrm{cd}}$ & $5.66^{\mathrm{e}}$ & $10.30^{\mathrm{e}}$ & $45.09^{\mathrm{a}}$ \\
\hline $\mathrm{VCN}_{0}$ & $22.75^{\mathrm{abc}}$ & $4.60^{\mathrm{d}}$ & $6.42^{\text {cde }}$ & $11.02^{\text {cde }}$ & $42.31^{\mathrm{abc}}$ \\
\hline $\mathrm{VCN}_{100}$ & $22.12^{\mathrm{bcd}}$ & $4.80^{\mathrm{bcd}}$ & $7.19^{\text {bcde }}$ & $11.99^{\text {bcde }}$ & $40.02^{\mathrm{abc}}$ \\
\hline $\mathrm{VCN}_{150}$ & $22.65^{\mathrm{abcd}}$ & $5.15^{\mathrm{abc}}$ & $7.53^{\mathrm{abc}}$ & $12.68^{\mathrm{abc}}$ & $40.60^{\mathrm{abc}}$ \\
\hline $\mathrm{RHBN}_{0}$ & $21.30^{\text {de }}$ & $4.40^{\mathrm{d}}$ & $7.02^{\text {bcde }}$ & $11.42^{\text {cde }}$ & $38.74^{\mathrm{bc}}$ \\
\hline $\mathrm{RHBN}_{100}$ & $21.85^{\mathrm{cde}}$ & $4.41^{\mathrm{d}}$ & $6.78^{\text {bcde }}$ & $11.20^{\text {cde }}$ & $39.44^{\mathrm{abc}}$ \\
\hline $\mathrm{RHBN}_{150}$ & $23.10^{\mathrm{abc}}$ & $4.56^{\mathrm{d}}$ & $6.41^{\text {cde }}$ & $10.97^{\mathrm{de}}$ & $41.49^{\mathrm{abc}}$ \\
\hline $\mathrm{CDN}_{0}$ & $22.90^{\mathrm{abc}}$ & $4.49^{d}$ & $6.05^{\mathrm{cde}}$ & $10.54^{\mathrm{e}}$ & $42.63^{a b c}$ \\
\hline $\mathrm{CDN}_{100}$ & $23.10^{\mathrm{abc}}$ & $4.91^{\mathrm{abcd}}$ & $6.59^{\text {cde }}$ & $11.50^{\text {cde }}$ & $42.72^{\mathrm{abc}}$ \\
\hline $\mathrm{CDN}_{150}$ & $22.95^{\mathrm{abc}}$ & $5.18^{\mathrm{ab}}$ & $7.18^{\text {bcde }}$ & $12.36^{\mathrm{bcd}}$ & $41.89^{\mathrm{abc}}$ \\
\hline $\mathrm{PMN}_{0}$ & $23.65^{\mathrm{a}}$ & $5.22^{\mathrm{ab}}$ & $7.33^{\text {bcd }}$ & $12.55^{\text {bcd }}$ & $41.62^{\mathrm{abc}}$ \\
\hline $\mathrm{PMN}_{100}$ & $23.45^{\mathrm{ab}}$ & $5.36^{\mathrm{a}}$ & $8.28^{\mathrm{ab}}$ & $13.70^{\mathrm{ab}}$ & $39.52^{\mathrm{abc}}$ \\
\hline $\mathrm{PMN}_{150}$ & $23.65^{\mathrm{a}}$ & $5.41^{\mathrm{a}}$ & $8.97^{\mathrm{a}}$ & $14.34^{\mathrm{a}}$ & $37.57^{\mathrm{c}}$ \\
\hline $\mathrm{CV}(\%)$ & 2.90 & 5.17 & 10.53 & 11.78 & 6.57 \\
\hline $\mathrm{SE}( \pm)$ & 0.64 & 0.25 & 0.73 & 0.80 & 2.70 \\
\hline
\end{tabular}

Note: $\mathrm{RS}=$ Rice straw; $\mathrm{VC}=$ Vermicompost; $\mathrm{RHB}=$ Rice husk biochar; $\mathrm{CD}=$ Cowdung and $\mathrm{PM}=$ Poultry Manure.

In case of plant height, significantly maximum height was found in the poultry manure along with $\mathrm{N}_{150}$ dose which was $98.50 \mathrm{~cm}$ and the lowest height was found in the treatment combination of rice husk biochar with no $\mathrm{N}$ fertilizer $\left(\mathrm{N}_{0}\right)$ which was $78.5 \mathrm{~cm}$. Poultry manure in combination with $150 \mathrm{~kg} \mathrm{ha}^{-1} \mathrm{~N}$ dose significantly rendered the maximum number of tillers (20) and effective tillers (18) per hill, panicle length $(27.5 \mathrm{~cm})$, grains (145.0), filled grains (138.0) per panicle as well as 1000 grains weight $(23.65 \mathrm{~g})$, grain yield $\left(5.41 \mathrm{t} \mathrm{ha}^{-1}\right)$, straw yield $\left(8.97 \mathrm{t} \mathrm{ha}^{-1}\right)$ and biological yield $\left(14.34 \mathrm{t} \mathrm{ha}^{-1}\right)$ of $\mathrm{T}$. aman rice followed by $\mathrm{PMN}_{100}$ combination. The lowest number of tillers (8.5) and effective tillers (7.50) per hill and grain yield (4.40 $\left.\mathrm{t} \mathrm{ha}^{-1}\right)$ were recorded in $\mathrm{RHBN}_{0}$ treated plot. Poultry manure in combination with $150 \mathrm{~kg} \mathrm{ha}^{-1} \mathrm{~N}$ dose significantly rendered the maximum number of tillers (20) and effective tillers (18) per hill, panicle length $(27.5 \mathrm{~cm})$, grains (145.0), filled grains (138.0) per panicle as well as TSW (23.65 g), grain yield $\left(5.41 \mathrm{t} \mathrm{ha}^{-1}\right)$, straw yield $\left(8.97 \mathrm{t} \mathrm{ha}^{-1}\right)$ and biological yield $\left(14.34 \mathrm{t} \mathrm{ha}^{-1}\right)$ of $\mathrm{T}$. aman rice followed by $\mathrm{PMN}_{100}$ combination. The lowest number of tillers (8.5) and effective tillers (7.50) per hill and grain yield $\left(4.40 \mathrm{t} \mathrm{ha}^{-1}\right)$ were recorded in $\mathrm{RHBN}_{0}$ treated plot. The lowest panicle length $(18.5 \mathrm{~cm})$ was found in $\mathrm{RSN}_{100}$ and grains panicle ${ }^{-1}$ (121) was in $\mathrm{RHBN}_{100}$ treated plot. The minimum filled grains (112.0) and biological yield $\left(10.54 \mathrm{t} \mathrm{ha}^{-1}\right)$ was recorded in combined application of $\mathrm{RSN}_{0}$. Number of unfilled grains (5) were minimum in the $\mathrm{PMN}_{0}$ treated plot. While maximum number of unfilled grains (10.0) per panicle was recorded in plot received $\mathrm{RSN}_{0}$. Again, $\mathrm{HI}$ was found maximum in the $\mathrm{RSN}_{100}$ treatment combination and its lowest value was found in the $\mathrm{PMN}_{150}$ treated plot. Laila et al. showed that when organic and chemical fertilizers are used, the number of total tillers hill ${ }^{-1}$, effective tillers hill ${ }^{-1}$, and number of grains panicle ${ }^{-1}$, panicle length, grain yield, and straw yield all varied considerably [44]. Plant height, number of tillers per hill, spikelet number per panicle, grain production, and TSW were increased with the use of organic and chemical fertilizers according to findings [39]. Manures in combination with chemical fertilizers have also been shown to benefit effective tillers hill ${ }^{-1}$ [45]. Uptake and use of nutrients were increased as result of organic waste application in the rice field which enrich grain quality of rice [46]. In comparison to a single application of the recommended fertilizer dose, the combined application of fertilizers and manure enhanced plant height. According to study, organic manure and chemical fertilizers have a strong impact on plant height [47]. Because organic matter contains macro and micronutrients and combined applications of organic and inorganic fertilizers result in increased plant height [48]. The use of chemical fertilizer with organic manure resulted in a considerable increase in effective tillers hill $^{-1}$ [49]. When organic and inorganic fertilizer treatments were combined, the number of tillers per unit area increased [22]. Combined organic manures with fertilizers resulted in an increase in effective tillers hill ${ }^{-1}$ that was comparable to a $100 \%$ chemical treated treatment [20]. Chemical fertilizer combined with organic manure enhanced the TSW reported by Yang et al. [50]. According to Dwivedi and Thakur, the use of organic manure and chemical fertilizers enhanced grain yield considerably [51]. It is apparent that combining organic manure with chemical fertilizers promoted plant growth and as a result increased straw yield. Reddy et al. found significant effects of manures and fertilizers on straw yield [52]. Singh et al. and Rahman et al. concluded that using organic manure and chemical fertilizers increase rice grain and straw yields [53], [54]. Jahan et al. also reported that combining inorganic fertilizers and organic manures produced the highest straw yield [55]. Ali et al. found that integrated nutrient management resulted in a higher harvest index [37]. According several findings stated above it is evident that combined application of organic and inorganic fertilizers enhance the yield contributing characters of rice which is well consistent with this present study.

\section{CONCLUSION}

Organic materials play a vital role in improving soil health and productivity. Simultaneous application of OM and $\mathrm{N}$ fertilizer significantly influence the growth and yield of T. aman rice. Data revealed that application of different organic materials positively increase growth and yield parameters of T. aman rice. Among the applied OM poultry manure was found superior in terms of all the studied parameters while $150 \mathrm{~kg} \mathrm{ha}^{-1} \mathrm{~N}$ dose was found effective increasing in yield and yield contributing characters of rice. 
Interaction effect showed the significantly best performance of $\mathrm{T}$. aman rice fields received poultry manure along with $150 \mathrm{~kg} \mathrm{ha}^{-1} \mathrm{~N}$ dose. Present study suggests that application of PM along with $150 \mathrm{~kg} \mathrm{~N}$ can render superior crop growth and yield of $\mathrm{T}$. aman rice.

\section{ACKNOWLEDGEMENT}

Authors impressively acknowledge Krishi Gobeshona Foundation (KGF), Bangladesh, for financing this research through CRP-II project.

\section{CONFLICT OF INTEREST}

The authors declare there is no conflicts of interest.

\section{REFERENCES}

[1] Krishi Diary, Agriculture Information Service (AIS), Khamarbari, Dhaka. 2008, pp. 66.

[2] Yearbook of Production, Food and Agricultural Organization (FAO), Statistics Division, pp. 76-77.

[3] S. Islam, K. Parveen, M. I. K. Khan, M. M Rahman, and F. Ahmad, "Integrated use of organic manure with chemical fertilizers on the growth and yield of T. Aman rice," Journal of Science, Technology and Environment Informatics, vol. 03, no. 01, pp. 170-177, 2016.

[4] Bangladesh Rice Knowledge Bank (BRKB), Rice in Bangladesh, Training Division, Bangladesh Rice Research Institute (BRRI), Gazipur, 2021.

[5] M. Maniruzzaman, J.C. Biswas, M.B. Hossain, M.M. Haque, U.A. Naher, A. Biswas, A. K. Choudhury, S. Akhter, F. Ahmed, M. M. Rahman, and N. Kalra, "Evaluating the CERES-Rice model under dry season irrigated rice in Bangladesh: Calibration and validation," Journal of Agricultural and Crop Research, vol. 5, no. 6, pp. 96-107, 2017.

[6] G. M. Rahman, M. M., Rahman, M. S., Alam, M. Z. Kamal, H. A. Mashuk, R. Datta, and R. S. Meena, "Biochar and organic amendments for sustainable soil carbon and soil health. In Carbon and Nitrogen Cycling in Soil," Springer, Singapore, pp. 45-85, 2020.

[7] U. Muhammad, E. Ullah, E. A. Warriach, M. Farooq, and A. Liaqat, "Effect of organic and inorganic manures on gowth and yield and of rice variety Basmati- 2000," Intl. J. Agric. and Bio. Vol. 4, no. 4, pp. 481-483, 2003.

[8] S. M. A. Hossain, and M. S. Islam, "Fertilizer Management in Bangladesh," Adv. Agron. Res. Inst., Joydebpur, Gazipur. pp. 48-54, 2006.

[9] J. P. Reganold, I. P. Robert, and J.F. Parr, "Sustainability of agriculture in the United States-An overview. Proc. Sustainable Agriculture," Issues, Prospectives and Prospects in Semi-Arid Tropics. Singh, R.P. (ed.), 1990.

[10] M. A. Alam, M. M. Rahman, J. C. Biswas, S. Akhter, M. Maniruzzaman, A. K. Choudhury, M. A. H .S. Jahan, M. M. U. Miah, R. Sen, M. Z. U. Kamal, and M. A. Mannan, "Nitrogen transformation and carbon sequestration in wetland paddy field of Bangladesh ," Paddy and Water Environment, vol. 17, no. 4, pp. 677 688, 2019.

[11] K. K. M. Nambiar, "Long-term fertility effects on wheat productivity. Wheat for the non-traditional warm areas," Proceedings International Conference, Mexico, DF (Mexico) CIMMYT, 1991, pp. 516-521.

[12] Fertilizer Recommendation Guide, Bangladesh Agricultural Research Council (BARC), Dhaka, Bangladesh, 2005, BARC Soils Pub. No. 45.

[13] S. Sangeetha, A. Balakrishnan, and P. Devasenapathy, "Influence of Organic Manures on Yield and Quality of Rice (Oryza sativa L.) and Blackgram (Vigna mungo L.) in Rice-Blackgram Cropping Sequence," American Journal of Plant Sciences, vol. 4, no. 5, pp. 1151-1157, 2013.

[14] A. V. Dahiphale, D. G. Giri, G. V. Thakre, and M. D. Gin, "Effect of Integrated Nutrient Management on Yield and Yield Contributing Parameters of the Scented Rice," Annals of Plant Physiology, vol. 17, no. 1, pp. 4-26, 2003.

[15] H. Brammer, "The geography of the soils of Bangladesh," The University Press Limited, Dhaka, 1996, pp. 132-133.

[16] Fertilizer recommendation guide, Bangladesh Agricultural Research Council (BARC), Farmgate, Dhaka, 2012.
[17] M. Pramanik, D. Dutta, I. and Samui, "Effect of Seaweeds on Growth and Yield of Boro Rice (Oryza sativa L.)," Current Journal of Applied Science and Technology, vol. 39, no. 33, pp. 28-34, 2020.

[18] K. Moe, K. W. Mg, K. K. Win, and T. Yamakawa, "Combined effect of organic manures and inorganic fertilizers on the growth and yield of hybrid rice (Palethwe-1)," American Journal of Plant Sciences, vol. 8, no. 5, pp. 1022-1042, 2017.

[19] A. J. Mahmud, A. T. M. Shamsuddoha, and M. N. Haque, "Effect of organic and inorganic fertilizer on the growth and yield of rice (Oryza sativa L.)," Nature Science, vol. 14, no. 2, pp. 45-54, 2016.

[20] M. H. Sohela, A. Sarkera, M. A. Razzakb, \& M. A. Hashemc, "Integrated use of organic and inorganic fertilizers on the growth and yield of Boro rice (cv. BRRI dhan 29)," Journal of Bioscience and Agriculture Research, vol. 10, no. 1, pp. 857-865, 2016.

[21] D. Mekonnen, "Effects of integrated nutrient management on agronomic performance of potato (Solanum tuberosum. L.) and fertility of nitosol at Bako," MSc Thesis, Alemaya University, Ethiopia, 2006.

[22] M. Hasanuzzaman, K. U. Ahamed, N.M. Rahmatullah, K. N. Akhter, and M. L. Rahman, "Plant growth characters and productivity of wetland rice (Oryza sativa L.) as affected by application of different manures," Emir. J. Food Agric., vol. 22, no. 1, pp. 46-58, 2010.

[23] H. B. Miller, "Poultry litter induces tillering in rice," J. Sustain. Agric., vol. 31, pp. 1-12, 2007.

[24] B. C. Ghosh, C. V. Raghavaian, \& M. K. Jana, "Effect of seed rate and nitrogen on growth and yield of direct-sown rice (oryza-sativa) under intermediate deep-water condition," Indian Journal of Agronomy, vol. 36, pp. 227-228, 1991.

[25] S. K. Sarkar, M. A. R. Sarkar, N. Islam, and S. K. Paul, "Morphophysiological attributes of three HYV aromatic fine rice varieties as affected by integrated nutrient management," Journal of Agroforestry and Environment, vol. 10, no. 1, pp. 57-61, 2016.

[26] H. Belefant-Miller, "Poultry litter induces tillering in rice. Journal of sustainable Agriculture," vol. 31, no.1, pp. 151-160, 2007.

[27] A. Rakshit, N.C. Sarkar, and S. Debashish, "Influence of organic manures on productivity of two varieties of rice," J. Cent. Eur. Agric., vol. 9, no. 4, pp. 629-634, 2008.

[28] M. Idris, and M. A. Matin, "Response of four exotic strains of aman rice to urea," Bangladesh J. Agril. Sci, vol. 17, no. 2, pp. 271-275, 1990.

[29] V. Kumar, and O. P. Singh, "Effect of organic manures Nitrogen and Zinc fertilization on growth, yield, and yield attributes and quality of rice (Oryza sativa L),"J. Plant Sci. vol. 1, no. 2, pp. 311-314, 2006.

[30] M. G. Moula, "A study on relationship between physiological parameters and grain growth of boro rice," M.S. Thesis, Bangladesh Agricultural University, Mymensingh, pp. 1072002.

[31] E. E. Umanah, E. O. Ekpe, B. A. Ndon, M. E. Etim, \& M. S. Agbogu, "Effects of poultry manure on growth characteristics, yield and yield components of upland rice in South Eastern Nigeria," J. Sustainable Agric and the Environment, vol. 5, no. 1, pp. 105-110, 2003.

[32] S. Mohandas, V. Paramasivam, and N. Sakthivel, "Phosphorus and Zinc Enriched Organics for Enhancing the Yield of Transplanted Rice in New Cauvery Delta, Tamil Nadu," Journal of Ecobiology, vol. 23, no. 3, pp. 73-76, 2008.

[33] J. Yang and J. Zhang, "Grain-filling problem in "super' rice," Journal of Experimental Botany, vol. 61 no. 1, pp. 1-5, 2010.

[34] R. A. Ebaid, and I. S. EL-REFAEE, "Utilization of rice husk as an organic fertilizer to improve productivity and water use efficiency in rice fields," African Crop Science Conference Proceedings, vol. 8 pp. 1923-1928, 2007.

[35] J. A. Sci, F. Res, and H. Elhabet, "Effect of organic and inorganic fertilizers on rice and some nutrients availability under different water regimes," Journal of Agricultural and food Science vol. 9, pp. 1-16, 2018.

[36] M. A. Alim, "Effect of organic and inorganic sources and doses of nitrogen fertilizer on the yield of Boro rice," Journal of Environmental Science and Natural Resources, vol. 5, no. 1, pp. 273282, 2012.

[37] M. I., Ali, M. A. R Sarkar, and S. K. Paul, "Influence of plant nutrient management on the yield performance of transplant Aman rice (Oryza sativa L.)," Archives of Agriculture and Environmental Science, vol. 3, no. 1, pp. 49-53, 2018.

[38] M. A. Alam, M. M. Rahman, M. Z. Kamal, H. Kabir, M. Shiragi, S. Monira, and M. Hasnat, "A study on organic matter and nitrogen dynamics in wetland paddy soils of Bangladesh," Archives of Agriculture and Environmental Science, vol. 4, no. 1, pp. 1-7, 2019.

[39] M. Siavoshi, A. Nasiri, and S. L. Laware, "Effect of organic fertilizer on growth and yield components in rice (Oryza sativa L.)," Journal of Agricultural science, vol. 3, no. 3, pp. 217, 2011. 
[40] F. Akter, M. M. Rahman, and M. A. Alam, "Long-term fertilization effect on yield and land productivity of rice-wheat cropping system of Bangladesh," Archives of Agriculture and Environmental Science, vol. 4, no. 2, pp. 249-255, 2019.

[41] A. Shah, M. Shafi, J. Bakht, W. Mohammad, M. T. Jan, M. J. Khan, and Z. Shah, "Effect of integrated use of nitrogen on yield and N uptake of maize crop," Pakistan Journal of Botany, vol. 42, no. 5, pp. 3633-3638, 2010.

[42] K. Ali, F. Munsif, M. Zubair, Z. Hussain, M. Shahid, I. U. Din, and $\mathrm{N}$. Khan, "Management of organic and inorganic nitrogen for different maize varieties," Sarhad J. Agric, vol. 27, no. 4, pp. 525529,2011

[43] V. K. Arya, J. Singh, L. Kumar, A. K. Sharma, R. Kumar, P. Kumar, and P. Chand, "Character association and path coefficient analysis in wheat (Triticum aestivum L.)," Indian Journal of Agricultural Research, vol. 51, no. 3, pp. 245-251, 2017.

[44] L. Nowshin, M. A. Rahman, S. K. Paul, and R. Afrina, "Yield performance of aromatic fine rice as influenced by integrated use of vermicompost and inorganic fertilizers," Journal of the Bangladesh Agricultural University, vol. 18, no. 2, pp. 260-265, 2020.

[45] I. Chaturvedi, "Effect of nitrogenous fertilizers on growth, yield and quality of hybrid rice," J. Cent. Europ. Agri. Vol.6, no. 4, pp. 611$618,2005$.

[46] M. M. Rahman, "Nutrient-use and carbon-sequestration efficiencies in soils from different organic wastes in rice and tomato cultivation," Communications in Soil Science and Plant Analysis, vol. 44, no. 9, pp. 1457-1471, 2013.

[47] S. Babu, R. Marimuthu, V. Manivanna, and S. Ramesh-Kumer, "Effect of organic and inorganic manures on growth and yield of rice," Agric. Sci. Digest, vol. 21, no. 4, pp. 232-234, 2001.

[48] M. Usman, E. Ullah, E. A. Warrich, M. A. Earooq, \& A. Liaqat, "Effect of organic manures on growth and yield of rice variety "Basmati 2000," Int. J. Agric. Biol., vol. 5, pp. 481-483, 2003.

[49] D. R. Nayak, X. Babu, and T. K. Adhya, "Long-term application of compost influences mineral biomass and enzyme activities in a tropical Aeric Endoaquept planted to rice under flooded condition," Soil Microbiology \& Biochemistry, vol.39, no. 8, pp. 1897-1906, 2007.

[50] C. M. Yang, L. Yang, Y. Yang, and Z. Ouyang, "Rice root growth and nutrient uptake as influenced by organic manure in continuously and alternately flooded paddy soils," Agricultural Water Management, vol. 70, no. 1, pp. 67-81, 2004.

[51] D. K. Devivedi, and S. S. Thakur, "Effect of organic and inorganic fertilizers levels on productivity of rice (Oryza sativa) crop," Indian. Agron. Vol. 45, no. 3, pp. 568-574, 2000.

[52] G. S. Kumar, S. N. Reddy, and M. Ikramullah, "Effect of age of seedling and nitrogen level on performance of rice (Oryza sativa) under late planting," Indian Journal of Agricultural Sciences (India), 1995.

[53] R. P. Singh, P. K. Yadav, R. K. Singh, M. K. Singh, \& J. Singh, "Effect of chemical fertilizer, FYM and biofertilizer on performance of rice and soil properties," Crop Res. Vol. 32, pp. 283-285, 2006.

[54] M. S. Rahman, M. R. Islam, M. M. Rahman, and M. I. Hossain, "Effect of cowdung, poultry manure and urea-N on the yield and nutrient uptake of BRRI dhan 29," Bangladesh Research Publications Journal, vol. 2, pp. 552-558, 2009.

[55] S. Jahan, M.A.R. Sarkar, and S.K. Paul, "Effect of Plant Spacing and Fertilizer Management on the Yield Performance of BRRI dhan39 under Old Brahmaputra Floodplain Soil," Madras Agricultural Journal, vol. 104, no. 1-3 pp. 37-40, 2017. 